\title{
Natural Area Weeds: Mexican Petunia (Ruellia simplex) ${ }^{1}$
}

\author{
Sandra B. Wilson, Adrienne Burkhead, Carrie Reinhardt Adams, and Rosanna Freyre ${ }^{2}$
}

\section{Introduction}

Ruellia simplex (Mexican bluebell, Mexican petunia, or Britton's wild petunia) is an herbaceous perennial (USDA Hardiness Zone 8-11) in the family Acanthaceae. Five species of Ruellia are native to Florida, and three nonnative species are listed as naturalized in the state, including $R$. simplex (Wunderlin et al. 2016). There has been some confusion about the name of this species, commonly referred to as Ruellia brittoniana, Ruellia coerulea, Ruellia tweediana, or Ruellia malacosperma (USDA NRCS 2016; Wundelin et al. 2016). Ruellia simplex C. Wright was the name used when this species was first described in Cuba in 1870; therefore, it has taxonomic priority (Ezcurra and Daniel 2007). This name is now widely used in the horticultural trade and amongst state agencies and will therefore be used in this publication.

\section{Description}

Ruellia simplex is native to southern North America, southern South America, and the Antilles (Ezcurra and Daniel 2007). It is characterized by linear to lanceolate leaves 3 to 7 inches long with very prominent veins, oppositely arranged along the stem. Green to purple stems have prominent nodal swellings and vary in color with exposure to light and fertilizer levels. The purple, pedunculate flowers are funnelshaped and have five petals that are either solitary or appear in few-flowered cymes arising where the leaves attach to the stem. Cleistogamy (self-fertilization without flower opening) is known to occur (Khoshoo et al. 1969) and is characterized by small, tubular greenish-brown flowers that do not open but form fruits from self-pollination. Growers note flower production from June to October, but flowering has been recorded throughout the year in natural areas (FDEP 1998). Under natural day length, greatest flowering has been observed between the end of May to early November in central Florida landscapes (Freyre et al. 2012a). It is possible that the quantity of blossoms is related to the amount of light the plant receives. Plants in more direct sunlight have been observed to produce more flowers. The fruit is a longitudinal capsule up to 1 inch long, containing about 20 circular but flattened seeds. As they mature, the fruit dry and release the seeds explosively. When exposed to moisture, the seeds exude a mucous-like gel. Flower and fruit stages alternate year-round in Florida.

The ornamental features of Mexican petunia, its ability to grow in a wide range of conditions, and the numerous cultivars available in the nursery and landscape industry (Table 1), explain its popularity among consumers, landscapers, and growers (Hammer 2002; Gilman 1999; Wirth et al. 2004; Bechtloff et al. 2019).

\section{Preferred Habitat}

In natural areas, Mexican petunia escapes to marshy/ wet areas and often forms small, localized, vegetative colonies (Turner 1991; Figures 1 and 2). It typically has been observed in wet, disturbed sites, including drainage ditches, shores of ponds or lakes, and moist-to-wet wooded areas (Godfrey and Wooten 1981), with some populations

1. This document is ENH1155, one of a series of the Environmental Horticulture Department, UF/IFAS Extension. Original publication date January 2010. Revised November 2020. Visit the EDIS website at https://edis.ifas.ufl.edu for the currently supported version of this publication.

2. Sandra B. Wilson, professor; Adrienne Burkhead, former graduate student; Carrie Reinhardt Adams, associate professor; Rosanna Freyre, research scientist; Environmental Horticulture Department, UF/IFAS Extension, Gainesville, FL 32611.

The Institute of Food and Agricultural Sciences (IFAS) is an Equal Opportunity Institution authorized to provide research, educational information and other services

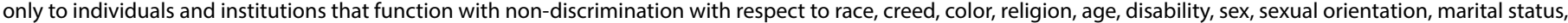

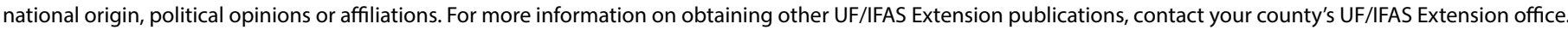
U.S. Department of Agriculture, UF/IFAS Extension Service, University of Florida, IFAS, Florida A \& M University Cooperative Extension Program, and Boards of County Commissioners Cooperating. Nick T. Place, dean for UF/IFAS Extension. 
noticeably expanding within a few years. However, it has considerable drought tolerance and survives in drier sites with full sun. Wilson et al. (2004) compared growth and reproduction of plants grown in wet and dry conditions and found that seedpod production was three times greater in wet conditions compared to dry conditions. They also found that stem length and shoot dry weights were 1.4 times greater in wet conditions.

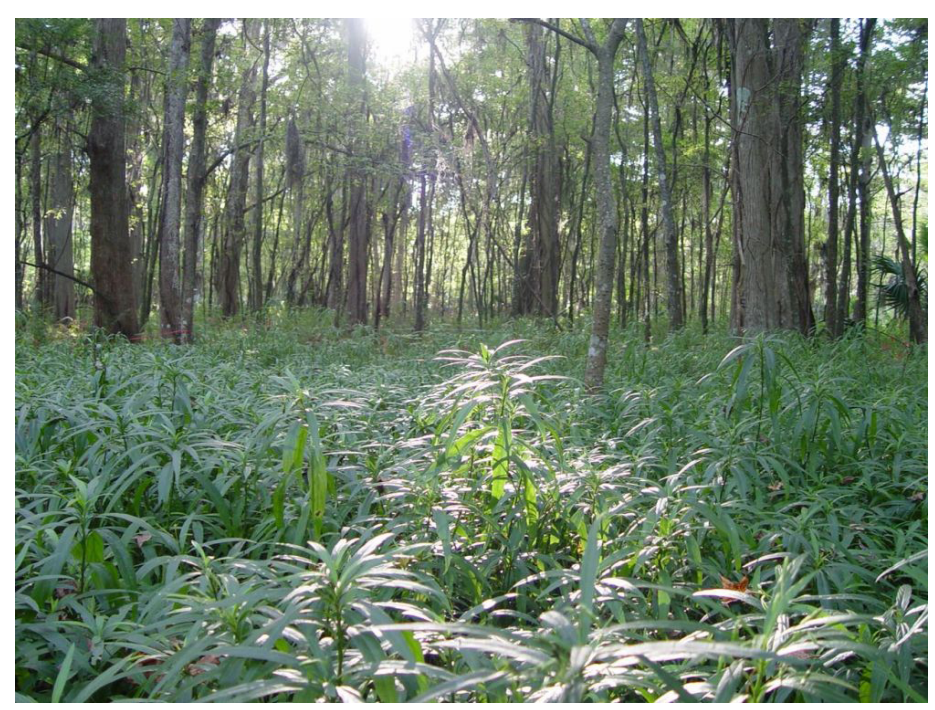

Figure 1. Monoculture of Mexican petunia (R. simplex) located in Payne's Prairie Preserve State Park, Alachua County.

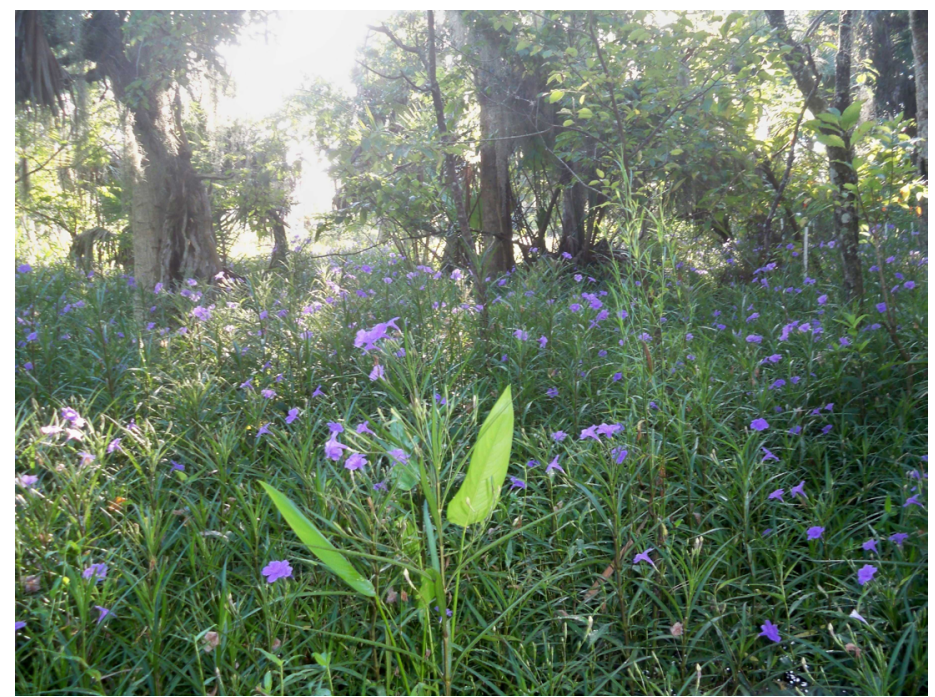

Figure 2. Monoculture of flowering Mexican petunia (R. simplex) located at the Lake Jesup Conservation Area in Seminole County.

\section{Dispersal}

Seeds lack dormancy mechanisms and are ready to germinate almost immediately after leaving the capsule. With no requirement for a cold treatment or seed coat damage scarification or stratification, seeds have a high germination rate occurring over a broad range of temperatures (Smith et al. 2015) with and without light (Wilson and Mecca 2003). In seed burial studies, environmental conditions of the soil inhibited germination of some seeds, but seeds germinated once placed in ideal conditions (Hupp 2007).

Literature describing the reproductive behavior of this species in natural areas is very limited. However, plants in the Acanthaceae have an explosive mechanism of seed dispersal. This helps Mexican petunia achieve seed dispersal up to 8-10 feet (Witzum and Schulgasser 1995). The mucus-like gel produced by these seeds when wet glues them to the soil surface when it dries (Gutterman et al. 1973), and can also help them stick to animals' fur or birds' feathers, helping their dispersal. Previous research found that seeds are not buoyant (Seitz 2015), but this characteristic does not inhibit dispersal. Seitz (2015) found that approximately 30,000 seeds/year and 10,000 stems/year are dispersed through streams during major stormwater events.

Mexican petunia is commercially propagated by seed or cuttings. Cuttings root readily without being treated with auxin. Mexican petunia is also capable of spreading vegetatively. Horizontal stems, both above and underground, root where the leaves are attached, giving rise to new plants.

\section{Hybridization between Ruellia Species}

Extensive artificial hybridizations were conducted in the genus Ruellia in the 1960s and 1970s to understand genetic relationships between species for taxonomic purposes (Long 1966; Long 1974; Khoshoo et al. 1969). Natural hybrids between $R$. caroliniensis, $R$. strepens, $R$. pedunculata, and $R$. purshiana were reported (Long 1974). Additionally, $R$. caroliniensis produced artificial hybrids after hand pollination with $R$. geminiflora, $R$. harveyana, R. humilis, and $R$. pedunculata. Artificial hybridization between $R$. caroliniensis and $R$. simplex was reportedly not successful (Long 1974). However, the same cross recently yielded a few interspecific hybrids, all of which were extremely weak and sterile. Therefore, it appears that the risk of gene flow from the invasive R. simplex to Florida native R. caroliniensis is negligible (Freyre and Tripp 2014).

\section{Cultivars}

The wild-type form of Mexican petunia is ornamentally inferior to the cultivated forms and is rarely offered for sale. Currently, there are eight known cultivars that have been selected commercially for pink, purple, or white flowers as well as tall and dwarf forms, none of which are patented (Table 1). They are easily propagated by cuttings or seed. Seed-propagated cultivars of dwarf forms have been released by Ball Seed. A bicolored form with white petals 
and a purple corolla tube has been identified in a landscape but is not in production (S. Wilson, personal communication). The cultivars reportedly are weedy in cultivation with some seedlings having the typical growth form of the species (Hammer 2002). Wilson and Mecca (2003) evaluated a wild type selection of Mexican petunia and eight cultivars ('Chi Chi,' 'Morado Chi', 'Katie Variegated,' 'Purple Showers, 'Snow White, 'Katie Pink', 'Katie Purple', and 'Katie White') and found that seed production, germination, and relative growth rate were highly variable among cultivars. Their study revealed that the cultivar 'Purple Showers' did not set any seed, whereas at least two other cultivars ('Morado Chi' and 'Chi Chi') set as much or more seed than the wild-type form with greater germination and viability. Other insightful data from their study revealed (1) seeds germinated under a wide range of temperature conditions with significant cultivar $\times$ light interactions, (2) after 6-12 months of storage at room temperature, seeds showed reduced rates of germination, and (3) dwarf cultivars were not true to type. Through flow cytometry analysis, the wild type form of Mexican petunia and cultivars 'Chi Chi', 'Katie Pink, 'Katie Purple,' 'Katie White', and 'McKee' appear to be diploids (with two sets of chromosomes), and 'Snow White' and 'Purple Showers' appear to be tetraploids (four sets of chromosomes) (Freyre, personal communication). Tetraploid cultivars can play an important role for crossing with diploids to produce triploid cultivars (three sets of chromosomes) with reduced fertility. The University of Florida Ornamental Breeding Program in Gainesville has released to date seven new cultivars with highly reduced (or nondetectable) fertility, named Mayan Purple ${ }^{\mathrm{rm}}$, Mayan White $^{\mathrm{rm}}$, Mayan Pink ${ }^{\mathrm{Tm}}$, and Mayan Compact Purple ${ }^{\mathrm{Tm}}$, Aztec Pink/White ${ }^{\mathrm{rax}}$, Aztec Pink ${ }^{\mathrm{Tw}}$, and Aztec Purple ${ }^{\mathrm{Tm}}$ (Freyre et al. 2012a; Freyre et al. 2012b; Freyre and Wilson 2014; Freyre et al. 2016). These cultivars were subjected to the Infraspecific Taxon Protocol by the UF/IFAS Invasive Plant Working Group and are now patented and in commercial production.

\section{Invasive Status and Distribution in Natural Areas}

Since its introduction sometime before 1940, Mexican petunia has naturalized in disturbed uplands and wetlands of 8 states (from South Carolina west to Texas, as well as Hawaii), the US Virgin Islands, and Puerto Rico (USDANRCS 2019). In Florida, it has formed naturalized populations in 29 counties throughout the state (Wunderlin et al. 2019). Herbarium samples of escaped Mexican petunia exist from counties extending from the northwestern tip of Florida all the way to the southern tip (Wunderlin et al.
2019; Table 2), suggesting the likelihood of its existence throughout the entire state.

In 2001, the Florida Exotic Pest Plant Council (FLEPPC) upgraded Mexican petunia from a Category II (potential problem) to Category I due to "altering native plant communities by displacing native species, changing community structures or ecological functions, or hybridizing with natives" and its status has not changed since (FLEPPC 2019). The Institute for Regional Conservation's database (IRC), "The Floristic Inventory of South Florida Database Online," contains distribution records of more than 2,400 species of plants in south Florida conservation areas. Mexican petunia is listed in 18 conservation areas in south Florida (Gann et al. 2008).

Mexican petunia has been observed in many natural areas across Florida. For example, a dense population of Mexican petunia can be found along the Sweetwater Branch Tributary in Paynes Prairie Preserve State Park in Alachua County. This population is exposed to frequent inundation in light and shade conditions. It can also be found growing in narrow zones along the edge of water ways at Hogtown Creek and other smaller creek beds in Alachua County. In Seminole County at Lake Jesup, Mexican petunia has become one large monoculture in a wetland under the cabbage palm hammock, even in the presence of grazing and trampling cows (Smith et al. 2016). Thus, most populations in natural areas were associated with water, and upland populations seemed likely to have persisted after deliberate planting and cultivation, or from populations that were established under wetter conditions (Hupp 2007).

In comparison, the native species $R$. caroliniensis grows in 56 of Florida's 67 counties (Wunderlin et al. 2019). Despite having a widespread distribution, it is typically found as only a few scattered plants at a time, not in dense monocultures. It does not show the narrow zonal distribution associated with water that is exhibited by Mexican petunia, though it is known to show similar habitat tolerances under cultivation.

\section{UF/IFAS Assessment}

Conclusions from the "University of Florida Institute for Food and Agricultural Science (UF/IFAS) Assessment of the Status of Non-native Plants in Florida's Natural Areas" state that the wild type of Mexican petunia is invasive and not recommended for use in any region of Florida (UF/ IFAS Invasive Plant Working Group 2019). However, the abovementioned Mayan and Aztec cultivars were evaluated through their Infra Taxon Protocol and approved for release 
and use with caution in all areas in Florida. More information can be found on the UF/IFAS Assessment page at http://assessment.ifas.ufl.edu/assessments/ruellia-simplex/.

\section{Control}

Eradication of this species may prove to be extremely difficult. Hand-pulling of this species can be effective for small areas or individual plants; however, all vegetative material must be removed to prevent vegetative regrowth from the underground rhizomes (Reinhardt Adams, Wiese, Lee et al. 2014). Mexican petunia seeds do not persist in the seedbank; this suggests that seeds germinate readily once released from the parent plant (Reinhardt Adams et al. 2015). Native seeds persist in the seedbank, but it is still unclear why native species are unable to recolonize after Mexican petunia control (Reinhardt Adams et al. 2015).

There are many safe and effective herbicides available to the homeowner for control of unwanted vegetation, and four of these products have been tested for effectiveness in controlling Mexican petunia. Tested products were all available at local hardware and home improvement stores, and they were all "ready-to-use" products, meaning they came in an applicator bottle and no mixing or diluting was required. It is important to note that product names often change, and the only way to be sure to purchase the same product that was used in this study is to compare the type and amount of active ingredient. This information is provided on the product label. The tested products are listed in Table 3, but the most commonly used and readily available product is Roundup (glyphosate) (Reinhardt Adams, Wiese, Lee et al. 2014). Follow all safety, application, and disposal requirements indicated on the product label.

These ready-to-use products are applied to the entire plant, covering as much of the upper and lower surfaces of the leaves and stems as possible, but stopping before herbicide drips off the plant. Because different products have different susceptibility to reduction in effectiveness from rainfall, effort should be made to apply herbicides during a period when rainfall is not expected for 24 hours.

For natural areas, a single application of herbicide, specifically Roundup, applied in the fall or spring is enough to initially control Mexican petunia (Reinhardt Adams, Wiese, and Cobb 2014). A follow-up application may be needed after 3-6 months, depending on regrowth (Reinhardt Adams, Wiese, Lee et al. 2014). If the first herbicide application does not kill the plants entirely, regrowth will come from either the tips of underground stems (rhizomes) or from sprouts along the bigger stems, near the base of the plant. Plants sprayed with Roundup exhibit regrowth almost exclusively from the bases of dead (treated) stems. Applications of other products usually also result in some regrowth from underground stems.

One field study showed that unassisted recolonization (i.e., plots where Mexican petunia was sprayed with herbicide but not planted or seeded with native species) did not result in Mexican petunia control and native plant establishment. In fact, even when planted seedlings of native species had adequate survival ( $2 \%-57 \%$ depending on species), reinvasion of Mexican petunia was not prevented (Smith et al. 2016). Smith et al. (2016) noted that Mexican petunia regrowth was primarily from rhizomes, not seed germination. More research is needed to determine effective herbicide methods that target rhizome growth, as well as refined revegetation approaches on both small- and largescale invasions in the longer term.

The effect of these products on other vegetation depends on many factors, such as which plant species are currently present and how tolerant of any particular product those species are. In one field study, the products, in increasing damage to non-Mexican petunia plant species, were Lawn Weed Killer, Weed-B-Gon, Roundup, and BrushB-Gon Poison Ivy Killer. In plots where Mexican petunia comprised more than $75 \%$ of the ground cover, within six months after herbicide application as much as $50 \%$ of the ground cover was non-Mexican petunia vegetation. NonMexican petunia vegetation was present in higher amounts after six months in sunny areas than in shaded areas.

\section{Conclusion}

Although Mexican petunia is an attractive and popular ornamental plant, the escape and establishment of this species in Florida's natural areas has had harmful ecological impacts. It is hoped that sterile cultivars will not escape and thus may be recommended for use by UF/IFAS, if approved using the newly implemented IFAS infraspecific taxon protocol. The species can be controlled in yards using ready-to-use herbicides. However, repeated treatments may be needed, and long-term management of large escaped populations will be costly.

\section{Literature Cited}

Bechtloff, A., C. Reinhardt-Adams, S. B. Wilson, and Z. Deng. 2019. "Alternatives to potentially invasive plant species for the horticultural industry in the southeast United States." J. Environmental Horticulture 37 (1): 9-18. 
Ezcurra, C., and T. F. Daniel. 2007. "Ruellia simplex, an older and overlooked name for Ruellia tweedinana and Ruellia coerulea (Acanthaceae)." Darwiniana 45:201-203.

Florida Department of Environmental Protection (FDEP). 1998. Florida Wetland Plants: An Identification Manual. Gainesville, FL: University of Florida Institute of Food and Agricultural Sciences. 228.

Florida Exotic Pest Plant Council. 2019. "Florida Exotic Pest Plant Council's 2019 list of invasive species." https:// www.fleppc.org/list/list.htm. Accessed July 2019.

Freyre, R., Z. Deng, G. W. Knox, V. Zayas, and S. Montalvo. 2016. "Fruitless Ruellia simplex R12-2-1 ('Mayan Compact Purple')." HortScience 51:1057-106. https://doi. org/10.21273/HORTSCI.51.8.1057

Freyre, R., A. Moseley, S. B. Wilson, and G. W. Knox. 2012a. "Breeding and evaluating for landscape performance and fruitlessness in Mexican petunia." HortScience 47:1245-1251.

Freyre, R., A. Moseley, S. B. Wilson, and G. W. Knox. 2012b. "Fruitless Ruellia simplex R10-102 ('Mayan Purple') and R10-108 ('Mayan White')." HortScience 47 (12): 1808-1814.

Freyre, R., and E. A. Tripp. 2014. "Artificial hybridization between U.S. native Ruellia caroliniensis and invasive Ruellia simplex: Crossability, morphological diagnosis, and molecular characterization." HortScience 49:991-996.

Freyre, R., and S. B. Wilson. 2014. "Ruellia simplex R10105-Q54 ('Mayan Pink')." HortScience 49:499-502.

Gann, G. D., K. A. Bradley, and S. W. Woodmansee. 2008. "The Floristic inventory of south Florida database online." https://regionalconservation.org/ircs/database/database. asp. Accessed June 2009.

Gilman, E. F. 1999. Ruellia brittoniana Mexican Bluebell. FPS513. Gainesville: University of Florida Institute of Food and Agricultural Sciences. https://edis.ifas.ufl.edu/fp513

Godfrey, R. K., and J. W. Wooten. 1981. Aquatic and Wetland Plants of the Southeastern United States-Dicotyledons. Athens, GA: University of Georgia Press. 708.

Gutterman, Y., A. Witztum, and W. Heydecker. 1973. "Studies of the surfaces of desert plant seeds. II. Ecological adaptations of the seeds of Blepharis persica." Annuals of Botany 37:1051-1055.
Hammer, R. L. 2002. "Mexican bluebell (Ruellia tweediana Griseb) A pretty invasive weed." Wildland Weeds 5:6-8.

Hupp, K. V. S. 2007. "Investigating the determinants of local scale distribution of Ruellia tweediana (synonym $R$. brittoniana) in natural areas." Thesis. University of Florida.

Khoshoo, T. N., R. C. Mehra, and K. Bose. 1969. "Hybridity, polyploidy and change in breeding system in a Ruellia hybrid." Theoretical and Applied Genetics 39:133-140.

Long, R. W. 1966. "Artificial hybridization experiments in Ruellia (Acanthaceae)." Am. J. Bot. 53:917-927.

Long, R. W. 1974. "Variation in natural populations of Ruellia caroliniensis (Acanthaceae)." Boll. Torry Bot. Club 101:1-6.

Lowrey, L. R. 1991. "Ruellia brittoniana var. katie." Amer. Nurseryman. 173 (3): 138.

Pickens, M. 1999. “Lynn Lowrey, Plantsman.” http://aggiehorticulture.tamu.edu/archives/parsons/heroes/lowrey2. html. Accessed: May 2009.

Plant Delights Nursery, Inc. 2003. "Juniper Level Botanic Gardens, Raleigh, NC.” http://www.plantdelights.com. Accessed May 2001.

Reinhardt Adams, C., C. Wiese, and L. C. Cobb. 2014. "Effect of season and number of glyphosate applications on control of invasive Mexican petunia (Ruellia simplex)." Ecological Restoration 32:133-137.

Reinhardt Adams, C., C. Wiese, L. C. Lee, S. B. Wilson, A. M. Smith, and R. Freye. 2014. Managing Mexican petunia (Ruellia simplex C. Wright) in the home landscape. EP498. Gainesville: University of Florida Institute of Food and Agricultural Sciences. https://edis.ifas.ufl.edu/ep498

Reinhardt Adams, C., C. Wiese, and L. C. Lee. 2015. "Native recolonization following control of invasive Ruellia simplex in a cypress floodplain forest." Applied Vegetation Science 18:694-704.

Seitz, J. 2015. "Stream-mediated dispersal mechanisms of invasive plants: Implication for management." University of Florida. Water, Wetlands \& Watersheds Seminar. Feb 11, 2015. 
Smith, A. M., C. Reinhardt Adams, C. Wiese, and S. B. Wilson. 2015. "Active revegetation efforts using native species do not promote invader control in the short term in a Ruellia simplex (Mexican petunia) invaded floodplain forest in Florida, USA." Journal of Applied Vegetation Science 19:20-30.

Smith, A. M., C. Reinhardt Adams, C. Wiese, and S. B. Wilson. 2016. "Re-vegetation with native species does not control the invasive Ruellia simplex in a floodplain forest in Florida, USA." Applied Vegetation Science 19:20-30.

Smith, A. M., S. B. Wilson, C. Reinhardt Adams, and C. Wiese. 2015. "Germination of native species: Efforts to guide revegetation in a Mexican petunia-invaded floodplain in Florida." Ecological Restoration 33:237-241.

Turner, B. L. 1991. “Texas species of Ruellia (Acanthaceae)." Phytologia 71 (4): 281-299.

UF/IFAS Invasive Plant Working Group. 2019. UF/IFAS Assessment of Non-native Plants in Florida's Natural Areas. http://assessment.ifas.ufl.edu/. Accessed July 2019.

USDA, NRCS (United States Department of Agriculture National Resources Conservation Service). 2019. The PLANTS Database, National Plant Data Center, Baton Rouge, LA. http://www.plants.usda.gov. Accessed July 2019.

Wilson, S. B., and L. K. Mecca. 2003. "Seed production and germination of eight cultivars and the wild-type of Ruellia tweediana: A potentially invasive ornamental." J. Environ. Hort. 21:137-143.

Wilson, S. B, P. C. Wilson, and J. A. Albano. 2004. "Growth and development of the native Ruellia caroliniensis and invasive Ruellia tweediana." HortScience 39:1015-1019.

Wirth, F. F., K. J. Davis, and S. B. Wilson. 2004. "Florida nursery sales and economic impacts of 14 potentially invasive ornamental plant species." J. Environ. Hort. 22:12-16.

Witzum, A., and K. Schulgasser. 1995. "The mechanics of seed expulsion in Acanthaceae." Journal of Theoretical Biology 176:531-542.

Wunderlin, R. P., B. F. Hansen, A. R. Franck, and F. B. Essig. 2019. Atlas of Florida Vascular Plants Institute for Systematic Botany, Univ. of South Florida, Tampa. http:// www.plantatlas.usf.edu. Accessed July 2019. 
Table 1. Botanical description, origin, and alternative names of wild-type Mexican petunia (R. simplex) and twelve cultivars.

\begin{tabular}{|c|c|c|}
\hline Cultivar/species & Similar cultivars & Botanical description and origin if known \\
\hline Wild type & & $\begin{array}{l}\text { 2-3 feet, upright growth, 1.4-inch-diameter purple flowers, narrower leaves than 'Purple } \\
\text { Showers' and wider than 'Morado Chi'; designated as a Category I invasive plant by the } \\
\text { Florida Exotic Pest Plant Council (FLEPPC 2019). }\end{array}$ \\
\hline 'Chi Chi' & 'Pink Showers' & 3-4 feet, upright growth, 2-inch-diameter pink flowers, narrow leaves \\
\hline 'Katie Pink' & 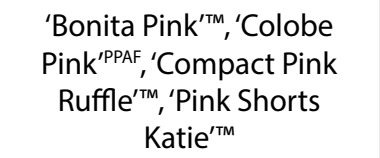 & $\begin{array}{l}\text { 6-12 inch compact form, 2-inch-diameter pink flowers, narrow leaves; discovered by Greg } \\
\text { Grant, who used 'Purple Katie' as the female parent to cross with the standard pink } R \text {. } \\
\text { simplex (Pickens 1999) }\end{array}$ \\
\hline 'Katie Purple' & $\begin{array}{l}\text { 'Compacta Katie,,'Dwarf } \\
\text { Katie','Purple Katie' }\end{array}$ & $\begin{array}{c}\text { 6-12 inch compact form, 2-inch-diameter purple flowers, narrow leaves; discovered in Texas } \\
\text { by employees Herbert Durand and Nolan Guillot (Lowrey 1991). }\end{array}$ \\
\hline 'Katie Variegated' & 'Strawberries and Cream' & $\begin{array}{l}\text { 6-12 inch compact form with variegated foliage, 2-inch-diameter purple flowers, narrow } \\
\text { leaves; discovered by Scott Reaves of Tree Search Farms in Texas in } 1994 \text { in a grouping of } \\
\text { 'Katie' (Plant Delights Nursery 2003). }\end{array}$ \\
\hline 'Katie White' & $\begin{array}{l}\text { 'Clean White Katie } e^{\prime \mathrm{TM}}, \text { 'Clean } \\
\text { White Shorts' }{ }^{\mathrm{TM}},{ }^{\prime} \text { Compact } \\
\text { White Ruffle }\end{array}$ & 6-12 inch compact form, 1.8-inch-diameter white flowers, narrow leaves. \\
\hline 'Morado Chi' & & 3-4 feet, upright growth, 1.8-inch-diameter purple flowers, very narrow leaves. \\
\hline 'Purple Showers' & 'Purple Fountain' & $\begin{array}{c}\text { 3-4 feet, upright growth, 2.2-inch-diameter purple flowers, leaves wider than the wild-type } \\
\text { species. }\end{array}$ \\
\hline 'Snow White' & 'Snow Queen', 'White Snow' & $\begin{array}{c}\text { 3-4 feet, upright growth, 1.8-inch-diameter white flowers, rounded leaves; sold as } R \text {. simplex } \\
\text { but may be a distinct species. }\end{array}$ \\
\hline Mayan Purple ${ }^{\mathrm{TM}}$ & & $\begin{array}{l}\text { Up to } 3 \text { feet, upright and full growth habit, } 1.8 \text { inch-diameter purple flowers, wide leaves, } \\
\text { less tall and prone to lodging than 'Purple Showers'; University of Florida release. }\end{array}$ \\
\hline Mayan White ${ }^{\mathrm{TM}}$ & & $\begin{array}{l}\text { Up to } 3 \text { feet, upright and full growth habit, } 1.8 \text { inch-diameter white flowers, wide leaves; } \\
\text { University of Florida release. }\end{array}$ \\
\hline Mayan Pink ${ }^{\mathrm{TM}}$ & & $\begin{array}{l}\text { 1-2 feet, upright growth, } 1.5 \text { inch-diameter pink flowers, narrow leaves. Some fruits may be } \\
\text { present; University of Florida release. }\end{array}$ \\
\hline $\begin{array}{l}\text { Mayan Compact } \\
\text { Purple }^{\mathrm{TM}}\end{array}$ & & $\begin{array}{l}\text { 1-2 feet, upright and full growth habit, } 1.8 \text { inch-diameter pink flowers, very wide leaves; } \\
\text { University of Florida release. }\end{array}$ \\
\hline Aztec Pink/White ${ }^{\mathrm{TM}}$ & & White flowers with pink center. University of Florida release. \\
\hline Aztec Pink ${ }^{\mathrm{TM}}$ & & Pink flowers with dark-pink center. University of Florida release. \\
\hline Aztec Purple ${ }^{\mathrm{TM}}$ & & Purple flowers with dark-purple center. University of Florida release. \\
\hline
\end{tabular}


Table 2. Florida counties in which Mexican petunia (R. simplex) has been documented (Wunderlin et al. 2019).

\begin{tabular}{|l|l|}
\hline Alachua & Miami-Dade \\
\hline Brevard & Monroe Keys \\
\hline Broward & Monroe Maitland \\
\hline Charlotte & Orange \\
\hline Citrus & Palm Beach \\
\hline Collier & Pinellas \\
\hline Escambia & Putnam \\
\hline Franklin & Sarasota \\
\hline Hendry & Seminole \\
\hline Highlands & St. Johns \\
\hline Hillsborough & St. Lucie \\
\hline Indian River & Sumter \\
\hline Lake & Volusia \\
\hline Lee & Wakulla \\
\hline Leon & Washington \\
\hline Levy & \\
\hline Manatee & \\
\hline Marion & \\
\hline
\end{tabular}

Table 3. Ready-to-use liquid (spray) herbicides tested for effectiveness in controlling Mexican petunia (R. simplex).

\begin{tabular}{|c|c|c|}
\hline Product & Chemical & Concentration \\
\hline Ortho Brush-B-Gon Poison Ivy Killer & Triclopyr triethylamine salt & $0.7 \%$ \\
\hline Ortho Weed B Gon Max & Mecoprop-p dimethylamine salt & $0.22 \%$ \\
$0.12 \%$ & $0.05 \%$ \\
\hline Ortho Basic Solutions Lawn Weed Killer & $2,4-$ D Dimethyl amine & Dicamba \\
\hline & 2,4 -D Dimethylamine salt & $0.326 \%$ \\
\hline & Mecoprop-p dimethylamine & $0.163 \%$ \\
\hline
\end{tabular}

